\title{
Conflict-induced Migration of Composers: An Individual-level Study
}

\author{
Karol Jan Borowiecki
}

TEP Working Paper No. 0511

March 2011

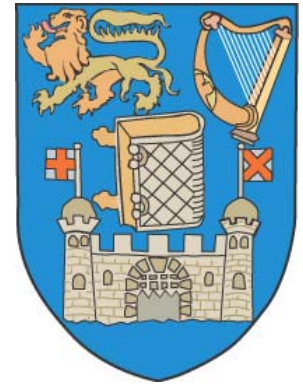

Trinity Economics Papers

Department of Economics

Trinity College Dublin 


\title{
Conflict-induced Migration of Composers: An Individual-level Study
}

\author{
Karol Jan Borowiecki \\ Trinity College Dublin
}

$\underline{A B S T R A C T}$

In this article we explore to what extent the incidence of war affects the probability to emigrate of 164 prominent classical composers born after 1800 . This study provides first insights on the decision making process of the forced migrant, the associated dynamics of conflict-induced migration and the determinants of choice of a destination country. We find that the incidence of inter-state wars increases composers' probability to emigrate by around seven percent and the incidence of intra-state wars by roughly nineteen percent. The results imply that conflict impacts the migration intensity with a lag of approximately one year. We also find that the choice of a destination country is inefficient in times of wars.

Keywords: migration, refugee, conflict, war, geographic concentration, composer

JEL Classifications: D74, F51, J61, Z10

Contact: Trinity College Dublin, Department of Economics, Dublin 2, Ireland. E-Mail: borowiek@tcd.ie. 


\section{Introduction}

The costs of war are manifold. One of the most disastrous aspects of war are conflict-induced displacements of populations. Millions of people have left their homes and seek as refugee asylum abroad. Such decisions to move are based on individual motivations. Little is however known about the decision making process of the forced migrant. It is also not clear what are the dynamics of forced migration and the determinants for choice of a destination country. The lack of such knowledge is particularly meaningful as the design of efficient policies for interventionism or delivery of efficient support for conflict-induced migrants becomes impossible.

The research on the causes and consequences of conflict-induced migration is hinderd by the lack of adequately disaggregated data. The usually employed data sets are available only for whole refugee communities and contain the caveat of over-aggregation. Therefore research on micro-motivations and incentives of forced migrants are mostly out of scope (Salehyan, 2007). There are no micro-level data sets available, because it is not feasible or secure to, for example, conduct representative surveys on migrants in regions where war takes place. In this article we overcome this problem by using historical data on prominent classical composers. It is the first attempt to identify the determinants of displacement at the individual level using rigorous statistical analysis. This article provides new, in a sense pioneering, insights on the decision-making processes of forced migrants.

The data set employed is extracted from large, comprehensive music dictionaries and it covers a global sample of 164 prominent classical composers born between 1800 and 1949. We find that the incidence of an international conflict increases composers' probability to emigrate by around seven percent and the incidence of civil war by roughly nineteen percent. We further shed light on the dynamics of individuals' decision making process and find that conflict impacts with a lag of approximately one year. The results indicate that while in times of peace the best composers are more likely to emigrate, in times of war, the probability of emigrate of the highest ranked composers decreases. The results also imply that the likelihood of emigration decreases for composers with strong personal ties. We also investigate the choice of a destination country and find that conflict-induced migrants make inefficient decisions with this regard. In times of war 
composers emigrate to countries that they already know and are familiar with, rather than, as it occurs in times of peace, to countries that would be beneficial for their career.

The rest of the study proceeds as follows. In the next section, we present related literature. In the third section, we introduce the data sources. In the fourth section, we present and discuss the empirical analysis, and in the last section, we provide concluding remarks.

\section{Literature}

There exists a large amount of influential research on the causes and consequences of conflict-induced migration. However, the data sets employed in this literature strand are usually available only on macro level and face the problem of overaggregation. The data is disposable only for whole refugee communities and does not allow for studies of micro-motivations and incentives that theorists emphasize (Salehyan, 2007). The data constraint is of particular importance as the decision to emigrate is clearly based on individual motivations and there are many personal factors that facilitate or impede migration, such as personal sensitivities, intelligence or awareness of conditions elsewhere (e.g. Peterson, 1958, Lee, 1966). Furthermore, Borjas (1987) demonstrates that not necessary the most skilled individuals decide to emigrate and argues that self-selection is a very important driver to migration. Once again, selfselection depends on the attributes of an individual. To our knowledge, the only microlevel study of conclict-induced migration is conducted by Engel and Ibanez (2007), who investigate the determinants of displacement for the case of Colombia. They use household-level surveys and estimate a random utility model of displacement. ${ }^{2}$

Previous studies demonstrate that the extent of forced migration varies for different types of conflict. Civil wars have generated the highest migration rates, followed by continental wars between states. The smallest emigration wave is caused by colonial wars (e.g. Schmeidl, 1997). Further studies investigate what country or war characteristics correlate most with forced migration and find violence as the most important determinant, be it government violence or dissident violence, while measures 
of economic conditions (e.g. GNP) are mostly insignificant (e.g. Moore and Shellman, 2004, Engel and Ibanez, 2007).

This study also relates to a number of studies within the literature of economic and social history. It is demonstrated that wars contain not only high direct costs but comprise also large indirect costs, such as a persistent decrease in bilateral trade, national income and global economic welfare (e.g. Findlay and O'Rourke, 2007), disadvantageous effects on relative prices (O'Rourke, 2007) or shrinkage of consumption (Goldin and Lewis, 1975). Or as argued more generally by social historians - wars are expensive, destructive and disruptive (e.g. Sorokin, 1937, Wright, 1965, Toynbee, 1972).

All in all this paper also contributes to the cultural economics literature. O'Hagan and Hellmanzik (2008) have demonstrated a marked clustering activity for visual artists and O'Hagan and Borowiecki (2010) for classical composers. The authors suggest that war could bring an artistic cluster to an end and shift it to another location. Such shifts are particularly meaningful given the importance of geographic clustering for creative production (e.g. Borowiecki, 2011), the incidence of conflict might have a profound impact on their migration intensity. The knowledge on geographic clustering or declustering, and also on the inter-temporal geographic shifts of creative clusters, is limited and based only on qualitative evidence. Borowiecki (2010) models the aggregate stock of composers in a country and argues that the negative impact of war on the number of artists is much larger in absolute terms than on the total population. The findings indicate an important cultural cost of conflict in form of the loss of creative individuals.

The weight of our findings is enforced by a number of studies that argue the importance of creative individuals to the development and attractiveness of a region. It is argued that the presence of cultural talent allows for higher quality of life (Nussbaum and Sen, 1993) and greater happiness (Layard, 2005) among the general population. In diverse locations the nature of cultural goods can change and develop (Addison, 2006). A rich culture of arts and entertainment attracts entrepreneurs and creative individuals from other disciplines to a cluster (Andersson and Andersson, 2006).

\footnotetext{
${ }^{2}$ Kondylis (2007) conducts also a household-level analysis and studies the determinants for return migration in post-conflict rural Rwanda. The survey used does not record however conflict-induced
} 


\section{Data}

In constructing the data set every effort was put into insuring maximum objectivity and reliability. The list of the most important composers is taken from Murray (2003) who provided a considerable and recognised survey of outstanding contributions to the arts and sciences from ancient times to the mid-twentieth century. Murray's work is based on numerous international references hence the risk of country- or marketing-biases in the selection is held to a minimum. The study of human accomplishment is conducted for several fields, including classical music, and for each outstanding individual in every discipline an index score is determined, based on the amount of space allocated to her or him in the reference works. The index score is normalised for all individuals listed in each disciplne so that the lowest score is 1 and the highest score is 100 .

Given the limited time availability of the population, GDP and war data sets, we restrict the composers' database to individuals born after 1800 . There are several implicit advantages of focusing on the $19^{\text {th }}$ and $20^{\text {th }}$ century. First, classical composers in this period were found to be extraordinary mobile individuals (O'Hagan and Borowiecki, 2010) and hence sensible migration analyzes become possible; especially as the geographic spread of composers is very high. They became market oriented agents with a remarkable entrepreneurial drive (Scherer, 2001). Next, data on the lives of composers are available and relatively reliable, as opposed to, for example, artists of earlier periods. Furthermore, the period chosen covers wars that significantly shaped most recent history and encompasses many of the most influential composers of all time. Finally, the period under consideration covers only deceased composers hence an analysis of whole life periods becomes possible. ${ }^{3}$

For the composers covered by this study we extract their background information and migration patterns from Grove Music Online (2009), the leading online source for music research, provided by Oxford University Press. ${ }^{4}$ This large multivolume dictionary contains detailed biographies of all composers encompassed by this study and it is "a critically organized repository of historically significant information" (Grove, 2009,

displacements but only return migration and hence is less relevant to the prime objective of this paper.

${ }^{3}$ See also Appendix 1 in Borowiecki (2010) for a summary of composers' conditions in the analyzed time period. 
Preface); therefore it is an ideal source for the purposes of this article.

The data on conflict is based on the Correlates of War (COW), a reliable database introduced and described by Sarkees (2000), and recognised by the broader scientific community. The COW data set identifies conflicts between states (inter-state wars) and within states (intra-state wars) that occurred between 1816 and 1997, and it lists a number of records for each war, e.g. the exact dates when a state became involved in a war and information on which continent the war occured, the number of battle-related deaths sustained by the participants' armed forces, the size of the pre-war population and prewar armed forces. ${ }^{5}$

The database allows to disagrate the war variable (i.e. Wartc) from the proposed specification (1) into inter-state war (i.e. war fought with an other state) and in intra-state war (i.e. war fought within state borders between government and non-government forces). In the case of inter-state wars, we will also differentiate between wars fought on the continent of the country and colonial wars, i.e. conflicts that occurred on other continents. This division is motivated by the ample difference between those two types of international conflict. Colonial wars, which are usually fought by wealthy states with a high international prestige, might impact composers' migration patterns in a very different way than continental wars.

The analyzed time period coincides with several changes in the political structure of countries, hence the following adjustments have to be made. As the authors of the conflict database aggregate the wars for Germany and Italy for the period before the unification in 1871 and during the $19^{\text {th }}$ century, respectively, we similarly aggregate composers for both states. For the years 1816-1918, during the existence of the AustriaHungary Union, the composers as well the wars in Austria and Hungary are aggregated. As all composers in Czechoslovakia (state existing from 1918 to 1993) were located within the boarders of Czech Republic, we use the contemporary name. Furthermore, in order to study the extent of war-related emigration from a country, the data set needs to be revised for composers who left the country in order to serve the army, sustained a

\footnotetext{
${ }^{4}$ Note that from now on with each reference to composer, we mean, prominent composer, the focus of this study. As the data encompasses only male composers, we use the male form.
} 
conflict-related death, or were imprisoned abroad in forced labour camps. Consequently a total of seven composers are excluded from the sample and as a result this study encompasses 164 prominent composers. ${ }^{6}$

The population and GDP per capita data sets are adapted from Maddison's (2006) widely cited statistics on world population. The data series are available annually, covering 1820 until 2006, for a number of countries. For a few missing years the population and GDP per capita series were linearly interpolated. Population is measured in thousands at mid-year and GDP per capita is measured in 1990 USD.

\section{Empirics}

This section describes and discusses the empirical analysis of this article. First we propose the econometric estimation framework. Second we report summary statistics. Third we present and discuss the relationship between war and migration intensity. Fourth we shed light on the heterogeneity of composers, and finally, we investigate what determines the choice of a particular destination country.

\subsection{Methodology}

We propose a model that estimates the probability to emigrate based on a specification at the individual year level:

$$
\begin{aligned}
\mathrm{P}\left(\text { Emigrate }_{\text {itc }}=1\right)=\beta_{0}+\beta_{1} \mathrm{War}_{\mathrm{tc}}+\beta_{2} \mathrm{Age}_{\text {itc }}+\beta_{3} \mathrm{Age}_{\text {itc }}^{2}+\beta_{4} \text { IndividualFE }_{\mathrm{i}}+ \\
+\beta_{5} \text { YearFE }_{\mathrm{t}}+\beta_{6} \text { CountryFE }_{\mathrm{c}}+\beta_{7} \mathrm{X}_{\text {itc }}+\varepsilon_{\text {ict }}
\end{aligned}
$$

We are primarily interested how the incidence of war in year $t$ and country $c$ impacts on the probability to emigrate of composer $i$ at year $t$ from country $c$. Therefore, of main interest is the coefficient $\beta_{1}$. In order to assure a robust estimation of the war impact, we introduce a number of control variables. We control for composer-specific time effects with a quadratic age polynomial (age $e_{i t c}$ and $a g e_{i t c}{ }^{2}$ ). The specification further contains

\footnotetext{
${ }^{5}$ The COW database also covers extra-state wars, i.e. wars between a state and a non-state entity. However, as none of these wars occurred within the boundaries of any of the countries where composers located in the analyzed time period, we will not include extra-state wars in our analysis.

${ }^{6}$ We exclude the following composers: Alban Berg, Henry Cowell, Olivier Messiaen, Nikolay Myaskovsky, Carl Orff, Richard Wagner and Ralph Vaughan Williams.
} 
individual fixed effects to take account of unobservable composers' heterogeneity, year fixed effects to deal with unobserved time heterogeneity and country fixed effects to account for difference between countries. In some specifications we also introduce further controls that could influence the decision to migrate (such as demand specific factors, e.g. national wealth). The standard errors $\left(\varepsilon_{\mathrm{it}}\right)$ are clustered at the composer level, allowing for correlations between observations of a single composer (within individual $i$ ), but remaining independent between composers (i.e. individual $i$ and $j$ do not have correlated errors). In this research design reverse causality is not an issue. The causal relationship between migration and war appears to be clear: war influences composers' migration intensity, not the other way round.

A possible criticism of our approach is that the involvement of a composer's country of residence in a war does not necessary mean that the artist must have witnessed the conflict. Nevertheless, we believe that direct experience of a war is not the only channel through which a creative individual might get affected. The impact might be indirect and could work for example through a change in a nations wealth due to a war and hence impact the demand, or through a change in societies cognition of security in times of war.

\subsection{Data Inspection}

A summary of composer's characteristics is presented in Table 1. The data set encompasses individuals who were engaged in music-related work during most of their lives (around 47 out of 69 years). The mean duration of music-related education or training, as recorded in the source, lasted around 7.5 years. Approximately 56 percent of the composers had at least one family member involved in a music-related activity (e.g. mother played piano, brother was a conductor). The mean Murray's Index Score is 7.7 with a marked right skewed distribution. Nearly one third of the composers were born in the first half of 19th century, a half was born in the second part of 19th century and the remaining artists were born in the 20th century. France and the Germanic countries accounted for the highest share of births of important composers - approximately 23 percent each, followed by Russia with 12 percent births, Italy and East European countries with each around 8 percent births. The fairly wide geographic spread of 
composers' births in connection with their high migration intensity enables a study of various wars that have occurred in several countries. In roughly nine percent of the yearly observations composers migrated, which indicates that they moved between countries almost six times during their lives. In the last panel of Table 1 we observe that composers' country of residence was involved during more than eight years in international wars and 0.88 years in civil wars. The artists encompassed by this study experienced on average 3.8 inter-state wars and 1.1 intra-state wars. The duration of international wars is 3.2 years and is higher than the duration civil wars (i.e. 2.4 years). Almost every composer lived at some stage during his life in a country engaged in an internation war and 54 out of the studied individuals lived in a country involved in an an intra-state conflict.

Preliminary evidence for higher emigration rates in times of war can be gathered in Table 2 where we summarize the probabilities to migrate depending on the presence or absence of a conflict. It can be observed in Panel A that the probability to emigrate in the absence of any inter-state war was around 8.7 percent. The coefficients decreases to $5.7 \%$ in times of international conflict and indicates that emigration was by around three percentage points less probable during inter-state wars. We next disaggregate the interstate war variable into wars fought on the continent of the country (i.e. continental wars) and wars that occurred on other continents (i.e. colonial wars). This division is motivated by the fundamental difference in the nature between those types of war. The colonial wars are fought in remote regions and should not have a detrimental effect to, for example, the cognition of security. Furthermore, the colonial wars are fought by wealthy states with a high international prestige and such wars could rather indicate the countries' overall economic and social welfare rather than the incidence of a conflict. As expected the difference in migration intensity differs substantially for continental and colonial wars. During continental wars the probability to emigrate reaches 11.5 percent. This indicates that composers were approximately 33 percent more likely to emigrate if a continental war occured. The derived propensity to migrate decreases during colonial wars by 4.5 percentage points. We observe also marked differences in the migration intensity depending on the presence or absence of intra-state wars. During civil wars the probability to emigrate increases sharply and indicates that composers are 7.3 percentage 
points more likely to leave their country of residence. All discussed differences are significantly different from zero at the usual confidence intervals.

\subsection{Migration and War}

Table 3 summarizes the results based on the proposed Model (1). All specifications are derived with controls for composers' age (estimated with a quadratic age polynomial) as well as fixed-effects for composers, years and countries.

In the regression reported in Column (1) we observe that continental wars correspond with a marked increase of the emigration rate. Composers were 11.6 percent more likely to depart from their country of residence during a continental war. The impact of intra-state wars is also positive albeit statistically undistinguishable from zero. The incidence of colonial wars has a negative impact on the emigration rate and the estimated coefficient indicates a 2.8 percentage decrease of the migration probability.

Due to the reasons described in the previous subsection, we drop the colonial wars variable out and re-estimate the correlations between emigration rates and the incidence of a continental war or intra-state war. The obtained point estimates, as reported in Column (2), remain positive and indicate that during continental wars or civil wars composers exposed consistently a higher propensity to emigrate. In Column (5) we further introduce controls for varying levels of demand and control for population size (size of the potential demand) as well as for GDP per capita (individual wealth). It is encouraging that the introduction of the demand controls hardly changes the findings.

An arising question concerns the dynamics of the war impact. It is important to understand whether higher emigration occurs in anticipation of the war or with a delay. Therefore, we study the lags and leads of the war variables and report the results in Column (4). The impact of continental wars remains high and significant in the year of the conflict and carries somewhat over to the next year. The influence of intra-state wars remains positive in the year the war occurs and rises considerably in the year afterwards. The importance of intra-state wars becomes visible with a delay of one year and the estimated coefficient indicates that composers were over nineteen percent more likely to emigrate as a result of a civil war in the previous year. Those effects disappear two years after the incidence of each conflict. There is no significant relationship between wars and 
migration intensity before the occurrence of the war. The total estimated impact of intrastate wars is greater than the effect of inter-state wars. The results are consistent with previous literature that found civil wars causing higher emigration rates than international conflicts.

The difference in the timing of the war effect on emigration might be caused by a consistent difference in the duration of continental wars and civil wars. As the continental wars last on average 0.8 years longer than intra-state wars (Table 1), composers have considerably more time to respond to the conflict and to emigrate. To analyse the possibility of a lagged response to war, we exclude all wars that lasted longer than one year. The findings for the restricted sample, that covers 137 inter-state wars and thirty intra-state wars of duration of one year, are presented in Column (5). The estimated coefficients for both types of war are much more comparable in their timing: continental wars and intra-state wars have the greatest effect on composers' emigration rates with an annual delay. Civil wars lead to a highly significant increase of the emigration rate in the following year by around 20 percent and continental wars increase the probability to emigrate by 6.6 percent (with a $p$-value of 0.12 ).

In the last specification (reported in Column (6)) we analyze the impact of wars on composers' immigration probabilities. The estimated coefficients are marginal in size and not significant. It is reassuring that the positive war-influence on the emigration rate disappears for the immigration intensity. This result confirms that the analyzed wars have a clear negative impact on the stock of composers in a country, rather than simply an influence on the migration intensity.

Each war is unique and capturing the incidence of a war with a dummy variable might not adequately account for its heterogeneity. In particular the varying level of warrelated violence, as suggested by recent research, might have a strong impact on migration rates. Therefore, we further introduce measures that account for varying intensities of conflict. We generate a variable that measures the number of battle-related deaths sustained by the participant's armed forces. ${ }^{7}$ In order to adjust the variable for differences in size between countries, as well as inter-temporal differences in country 
size, we express the battle-related deaths in relation to the pre-war population size. We further take account of varying durations of wars and express the term per year of duration of a conflict.

The results are reported in Appendix 1. The estimated point estimates for the warrelated deaths per population size are positive and statistically significant for both types of war. An annual battle-related loss of one percent of population during a continental conflict would increase composers' probability to emigrate by over ten percent and during civil war by around sixteen percent. It is encouraging that the results are consistent with the results discussed above as well as with findings from previous research: migration intensities increase with rising war-related violence and intra-state wars cause higher emigration rates.

\subsection{Heterogeneity of Migrants}

We further analyze the differences in the emigration rates depending on individuals' characteristics. We consider three different criteria and investigate which composers are most likely to emigrate. First, based on Murray's Index Score (MIS) we distinguish between composers quality. Second, we differentiate composers depending on the musical background of their family members. Third, we account for composers' musicrelated education or training times.

The heterogeneous war-effects on composers' emigration probabilities are reported in Table 4. Column (1) summarizes the baseline results. In Column (2) we investigate which individual characteristics correspond with higher emigration rates and include MIS, as a proxy for composers' quality, an indicator function for the presence of any music-related engagement of any family member and a measure of the duration of music-related education or training times. We find that composers with higher MIS are more likely to emigrate: ten points more on MIS result in an increase of the probability to emigrate by 11.5 percent. Composers with family members engaged in a music-related activity are by 56 percent less likely to emigrate and the chance to emigrate decreases by 9.2 percent for each additional year of music-related education or training times.

\footnotetext{
${ }^{7}$ For intra-state wars the number of deaths covers the total battle deaths of all participants, i.e. of the government and non-government forces. We believe that this measure takes best account of civil war
} 
In a further specification we combine the war variables and the three individual controls. The results are reported in Column (3). The main results can be confirmed: inclusion of the individual controls does not alter the war-effect on emigration. We also observe that the point estimates for the measures of composers' characteristics remain in general consistent in significance and sign.

We further introduce interaction terms and study how the war-impact differs depending on individual's traits. In Column (4) we introduce interaction terms between the conflict variables and MIS. We find negative coefficients for the interaction terms and positive estimates for the war terms on a stand-alone basis. The results imply that with a higher MIS, composers are less affected by war: the better artists are less likely to emigrate in times of conflict. We further include interaction terms between the war variables and the indicator function for music-related background of composers' family members. The findings, as can be viewed in Column (5), suggest that composers with no family member involved in a music-related activity are more probable to emigrate in times of war. The estimated effects are however relatively small in size and not significant at conventional significance levels. Next, we introduce interaction terms between the war variables and the duration of music-related education or training. The results, which are summarized in Column (6), indicate that composers with longer musicrelated education or training times are more likely to emigrate during war. Finally, we combine all discussed interaction terms and report the findings in Column (7). It is reassuring, that the estimated coefficients are mostly in coherence with the previously described estimates.

The results indicate that better composers are more likely to emigrate, albeit not in times of war. Presumably artists of higher quality have better possibilities to endure the war in the country of residence and are not as forced to emigration as composers of lower quality. Artists with none family member engaged in any music-related activity seem to be more likely to leave the country of residence, especially in times of war. It is possible that those composers have worse access to demand and related supply industries, and hence have worse possibilities to sustain a conflict without emigration. Individuals with longer music-related education or training times are in general more likely to emigrate

violence. 
and this probability remains high also during the incidence of war. It is likely that during music-related education composers gain access to a wider network of artists engaged in music-related activities and hence would face lower emigration cost.

\subsection{Destination of Migration}

An important question concerns the choice of a destination country: why does the forced migrant chose a particular destination? With the data set employed in this article we are able to overcome data limitations of previous research and we provide new insights on the determinants of choice of the destination country. We investigate the differences between the destination country and the origin country by focusing on a number of variables. We study whether the forced migrant has been before at the destination country and whether the destination country is the individual's country of birth. Furthermore, we analyze the differences in the number of composers, population size and GDP per capita between the destination and origin countries. ${ }^{8}$

We summarize the results in Table 5. In Column (1) we observe that 56 percent of all immigrations took place to a country that has been visited before by the migrant. Composers' birth country was chosen in around 28 percent times for the destination. We further find that individuals moved to countries with a 0.75 higher number of composers, 349 thousand lower population size and 110 USD more wealth per capita. In Columns (2) and (3) we disaggregate the observations into immigrations that are triggered by war, i.e. if war was present in the origin country, and moves that occurred in times of peace, i.e. during absence of war in the country of origin. The differences between those observations are summarized in Column (4). It can be viewed that if the move occured during war, composers are over nine percent more likely to immigrate to a country where they have been before. Artists are also four percent more prone to return to their country of birth if the move is triggered by war. Furthermore, if the migration is caused by the incidence of conflict in the origin country, composers are moving to a country with 2.1

\footnotetext{
${ }^{8}$ As the focus of this analysis lies on the choice of a particular country, rather than on modelling whether immigration occured, we do not use the Model (1). It would be preferred to estimate a model that accounts for differences in characteristics between all possible destination countries and the origin country, i.e. a model that would also provide insights on the issue why a composer has not choosen a particular country. We refrain however from this approach due to the lack of extensive data on all potential destinations, i.e. all countries that could have been choosen but were not.
} 
less composers, 25 million lower population size and 815 USD lower GDP per capita.

The emerging pattern is very clear and the findings add to the argument of Ibanez and Moya (2009) on the vulnerability of forced migrants. During times of war composers emigrate to countries where they have been before or where they have been born. It is likely that the decision to emigrate in times of war has been made under pressure and in an environment where life might be endangered and cognition of security is low. Therefore, composers' main motivation for the emigration is simply the exit from the country engaged in war and the move to a secure region. In times of peace, however, composers migrate to countries that seem to be better for them from the perspective of their carreers. The chosen destination, if there is no pressure in form of war, is a larger and wealthier country. Furthermore, it is a country with more classical composers hence it is benefitial for the career in classical music (Borowiecki, 2011).

\section{Conclusion}

In this article we provide new insights into the decision making process of forced migrants. We employ a unique database that contains background information and migration patterns of prominent classical composers, and link it with the occurrence of inter-state and intra-state wars for the time period 1816 to 1997 . We find that the incidence of continental inter-state war increases composers' probability to emigrate by approximately seven percent and the incidence of civil war leads to around nineteen percent higher emigration propensities. The findings are consistent with previous research conducted on the causes of war-related migration: wars within states lead to higher emigration rates compared with wars between states. Our results are also in coherence with previous findings of increasing refugee flows with higher war-related violence. We further find that conflict impacts individual's migration intensity with a lag of around one year and we provide an analysis of the characteristics of forced migrants. We finally investigate the choice of a destination country and find that conflict-induced migrants make inefficient choices. In times of war composers emigrate to countries that they already know and are familiar with, instead of choosing countries that would be beneficial for their career.

This paper, apart complementing studies on the magnitude and dynamics of 
forced migration, adds to the understanding of the marked shifts of artistic clusters. The incidence of conflict is a significant driver of composers' emigration intensity and hence wars might have contributed to geographic shifts of creative clusters. Considering the research on the importance of creative individuals for a region, the loss of the most talented individuals should be regarded as an important cultural cost of conflict that is faced by countries engaged in warfare.

If one believes in generality of the results from this research, policy implication can be derived for authorities responsible for interventionism of forced migration or delivery of support for conflict-induced migrants. If forced migrants choose the destination country based on its associated security levels, refugee flows can be directed by influencing the perception of safety of a destination region. Such interventionism might also increase the efficiency of migration flows. Next, the conflict-induced emigration rate of creative individuals might be decreased by targeted improvement of life conditions and work possibilities in the country of origin. These prescriptions are proposed with the premonitory note that further micro-empirical research and careful case studies are needed to denote precise causal channels and to design more effective policy responses. 


\section{Acknowledgments}

An earlier version of this paper was presented at the European Workshop of Cultural Economics (Aydin), at the ESTER/GLOBALEURONET Research Design Course (Barcelona) and at invited seminars at University College Dublin and University of the Basque Country. This work greatly benefited thanks to comments from Victoria AtecaAmestoy, Catia Batista, Stefano Battilossi, Javier Gardeazabal, John O’Hagan, Jeffrey Williamson, participants at the mentioned conferences and seminars and two anonymous referees at the European Review of Economic History. The author acknowledge's the excellent research assistance provided by Jean and James, and a generous research fund provided by John O’Hagan. 


\section{References}

Addison, T. 2006. "The International Mobility on Cultural Talent." UNU-WIDER Research Paper, 108.

Andersson, A.E. and D.E. Andersson. 2006. The Economics of Experiences, the Arts and Entertainment. Northhampton (MA): Edward Elgar Publishing.

Borjas, G.J. 1987. "Self-Selection and the Earnings of Immigrants." The American Economic Review, 77(4):531-553.

Borowiecki, Karol J. 2010. "Are composers different? Historical Evidence on ConflictInduced Migration." IIIS Discussion Paper No. 342.

Borowiecki, Karol J. 2011. "Geographic Clustering and Productivity: An Instrumetnal Variable Approach for Classical Composers." Trinity College Dublin Working Paper.

Engel, S. and A.M. Ibanez. 2007. "Displacement Due to Violence in Colombia: A Household-Level Analysis." Economic Development and Cultural Change, 55:335-365.

Findlay, R. and K.H. O'Rourke. 2007. Power and Plenty: Trade, War and the World Economy in the Second Millennium. Princeton: Princeton University Press.

Goldin C.D. and F.D. Lewis. 1975. "The Economic Cost of the American Civil War: Estimates and Implications." Journal of Economic History, 35(2):299-326.

Grove Music Online, Oxford Music Online. 2009. Oxford University Press. http://www.oxfordmusiconline.com (accessed March-November 2009).

Hazem G., P. Huth, and B.M. Russett. 2003. "Civil Wars Kill and Maim People-Long after the Shooting Stops." American Political Science Review, 97(2):189-202.

Ibanez, A.M. and A. Moya. 2009. "Vulnerability of Victims of Civil Conflicts: Empirical Evidence for the Displaced Population in Colombia." World Development, 38(4): 647-663.

Kondylis, F. 2008. "Agricultural Households and Conflict Displacement: Evidence from a Policy Intervention in Rwanda." Economic Development and Cultural Change, 57(1): 31-66.

Layard, R. 2005. Happiness: Lessons from a New Science. London: Allen Lane.

Lee, E.S. 1966. “A Theory of Migration.” Demography, 3(1):47-57.

Madisson, A. 2006. Historical Statistics for the World Economy, 1-2006 AD, http://www.ggdc.net/maddison (accessed on 04.03.2009). 
Moore W. and S. Shellman. 2004. "Fear of Persecution: Forced Migration, 1952-1995." Journal of Conflict Resolution, 40(5):723-45.

Murdoch J. and T. Sandler. 2002, "Economic Growth, Civil Wars, and Spatial Spillovers." Journal of Conflict Resolution, 46(1):91-110.

Murray, C. 2003. Human Accomplishment - The Pursuit of Excellence in the Arts and Sciences, 800 B.C. to 1950. New York: Harper Collins.

Nussbaum, M. and A. Sen. 1993. The Quality of Life. Oxford: Oxford University Press for UNU-WIDER.

O'Hagan, John and Karol J. Borowiecki. 2010. "Birth Location, Migration and Clustering of Important Composers: Historical Patterns." Journal of Historical Methods, 43(2): 81-90.

O'Hagan, John and Christiane Hellmanzik. 2008. "Clustering and Migration of Important Visual Artists: Broad Historical Evidence", Journal of Historical Methods, 41(3): 121-136.

O'Rourke, K.H. 2007. "War and welfare: Britain, France, and the United States 180714." Oxford Economic Papers, 59:8-30.

Peterson, W. 1958. “A General Typology of Migration.” American Sociological Review, 23(3):256-66.

Salehyan, I. 2007. "Refugees and the Study of Civil War." Civil Wars, 9(2):127-41.

Sarkees, M.R. 2000. "The Correlates of War Data on War: An Update to 1997." Conflict Management and Peace Science, 18(1):123-44.

Scherer, F.M. 2001. "The Evolution of Free-Lance Music Composition, 1650-1900." Journal of Cultural Economics, 25:pp.307-19.

Schmeidl, S. 1997. "Exploring the Causes of Forced Migration: A Pooled Time-Series Analysis, 1971-1990." Social Science Quarterly, 78(2):284-307.

Sorokin, P.A. 1937. Social and Cultural Dynamics, Vol. 3. New York: American Book. Toynbee, A. 1972. A study of history. New York: Oxford University Press.

Wright, Q. 1965. A study of war (2nd ed.). Chicago: University of Chicago Press.

Zolberg A., A. Suhrke, and S. Aguayo. 1989. Escape from Violence: Conflict and the Refugee Crisis in the Developing World. New York: Oxford University Press. 


\section{Tables}

TABLE 1. Summary Statistics $(n=171)$.

\begin{tabular}{|c|c|c|}
\hline & Mean & $\begin{array}{l}\text { Standard } \\
\text { Deviation }\end{array}$ \\
\hline & \multicolumn{2}{|c|}{ A. Background information } \\
\hline Life span (in years) & 69.45 & 15.18 \\
\hline Duration of Career (in years) & 46.55 & 15.71 \\
\hline Music-related education or training time (in years) & 7.57 & 6.01 \\
\hline Music-related engagement of any family member & 0.56 & 0.41 \\
\hline \multirow[t]{2}{*}{ Murray's Index Score } & 7.74 & 10.80 \\
\hline & \multicolumn{2}{|c|}{ B: Birth cohort } \\
\hline Birth cohort 1800-1849 & 0.32 & 0.47 \\
\hline Birth cohort 1850-1899 & 0.54 & 0.50 \\
\hline \multirow[t]{2}{*}{ Birth cohort 1900-1949 } & 0.14 & 0.34 \\
\hline & \multicolumn{2}{|c|}{ C. Birth country } \\
\hline British Isles & 0.07 & 0.26 \\
\hline France & 0.23 & 0.42 \\
\hline Germanic Countries & 0.23 & 0.42 \\
\hline Italy & 0.08 & 0.28 \\
\hline Russia & 0.12 & 0.33 \\
\hline Eastern Europe & 0.08 & 0.13 \\
\hline Rest of Europe & 0.06 & 0.30 \\
\hline \multirow[t]{2}{*}{ Rest of World } & 0.11 & 0.11 \\
\hline & \multicolumn{2}{|c|}{ D. Migration } \\
\hline Migration (per annum) & 0.09 & 0.28 \\
\hline \multirow[t]{2}{*}{ Migration (per composer) } & 5.95 & 3.90 \\
\hline & \multicolumn{2}{|c|}{ E. Wars experienced by a composer } \\
\hline Inter-state wars (in years) & 8.34 & 6.21 \\
\hline Intra-state wars (in years) & 0.88 & 1.88 \\
\hline Inter-state wars (count) & 3.81 & 1.87 \\
\hline Intra-state wars (count) & 1.13 & 1.27 \\
\hline Duration of inter-state wars (in years) & 3.20 & 2.14 \\
\hline Duration of intra-state wars (in years) & 2.39 & 3.21 \\
\hline Number of comp who experienced inter-state war & 152 & - \\
\hline Number of comp who experienced intra-state war & 54 & - \\
\hline
\end{tabular}


TABLE 2. Migration and War. Descriptive Evidence.

\begin{tabular}{|c|c|c|c|}
\hline & $\begin{array}{c}\text { Emigration if } \\
\text { war absent } \\
(1)\end{array}$ & $\begin{array}{c}\text { Emigration if } \\
\text { war present } \\
(2)\end{array}$ & $\begin{array}{r}\text { Difference } \\
(2)-(1) \\
\end{array}$ \\
\hline & \multicolumn{3}{|c|}{ A. War (Inter-state) } \\
\hline All inter-state wars & $\begin{array}{c}0.0867 \\
(0.0027)\end{array}$ & $\begin{array}{c}0.0576 \\
(0.0114)\end{array}$ & $\begin{array}{l}-0.0291^{*} \\
(0.0140)\end{array}$ \\
\hline Continental wars & $\begin{array}{c}0.0850 \\
(0.0026)\end{array}$ & $\begin{array}{c}0.1147 \\
(0.0216)\end{array}$ & $\begin{array}{c}0.0296^{*} \\
(0.0191)\end{array}$ \\
\hline Colonial wars & $\begin{array}{c}0.0866 \\
(0.0027)\end{array}$ & $\begin{array}{c}0.0415 \\
(0.0129)\end{array}$ & $\begin{array}{l}-0.0451^{*} \\
(0.0182)\end{array}$ \\
\hline Intra-state war & $\begin{array}{c}0.0851 \\
(0.0026)\end{array}$ & $\begin{array}{c}0.1579 \\
(0.0421)\end{array}$ & $\begin{array}{l}0.0728^{*} \\
(0.0322)\end{array}$ \\
\hline
\end{tabular}

\footnotetext{
NOTE: Standard errors are in parentheses. * denotes coefficients that are different from zero at the $10 \%$ confidence interval.
} 
TABLE 3. Migration and War.

\begin{tabular}{|c|c|c|c|c|c|c|}
\hline \multirow{2}{*}{$\begin{array}{c}\text { EXPLANATORY } \\
\text { VARIABLES }\end{array}$} & emigrate & emigrate & emigrate & emigrate & emigrate & immigrate \\
\hline & (1) & $(2)$ & (3) & (4) & (5) & (6) \\
\hline \multirow{2}{*}{ Continental war $(t+2)$} & & & & 0.0234 & 0.0163 & \\
\hline & & & & $(0.0350)$ & $(0.0374)$ & \\
\hline \multirow[t]{2}{*}{ Intra-state war $(\mathrm{t}+2)$} & & & & -0.0293 & -0.0360 & \\
\hline & & & & $(0.0278)$ & $(0.0246)$ & \\
\hline \multirow[t]{2}{*}{ Continental war $(t+1)$} & & & & 0.0484 & 0.0665 & \\
\hline & & & & $(0.0422)$ & $(0.0547)$ & \\
\hline \multirow[t]{2}{*}{ Intra-state war $(t+1)$} & & & & $0.193^{\star *}$ & $0.199^{\star *}$ & \\
\hline & & & & $(0.0876)$ & $(0.0918)$ & \\
\hline \multirow[t]{2}{*}{ Continental war (t) } & $0.116^{\star * *}$ & $0.0707^{\star \star}$ & $0.0660^{* *}$ & $0.0726^{* *}$ & -0.0206 & 0.00325 \\
\hline & $(0.0448)$ & $(0.0300)$ & $(0.0283)$ & $(0.0315)$ & $(0.0329)$ & $(0.0174)$ \\
\hline \multirow[t]{2}{*}{ Intra-state war (t) } & 0.0181 & 0.0168 & 0.0179 & 0.0234 & 0.0410 & -0.00958 \\
\hline & $(0.0305)$ & $(0.0302)$ & $(0.0304)$ & $(0.0330)$ & $(0.0825)$ & $(0.0236)$ \\
\hline \multirow[t]{2}{*}{ Continental war (t-1) } & & & & -0.0217 & $-0.0339^{* *}$ & \\
\hline & & & & $(0.0165)$ & $(0.0165)$ & \\
\hline \multirow[t]{2}{*}{ Intra-state war (t-1) } & & & & 0.00749 & 0.0670 & \\
\hline & & & & $(0.0420)$ & $(0.0852)$ & \\
\hline \multirow[t]{2}{*}{ Colonial war (t) } & $-0.0285^{\star \star}$ & & & & & \\
\hline & $(0.0122)$ & & & & & \\
\hline \multirow[t]{2}{*}{ log(Population) } & & & -0.0601 & & & \\
\hline & & & $(0.0480)$ & & & \\
\hline \multirow[t]{2}{*}{ GDP pc } & & & $-0.00868^{*}$ & & & \\
\hline & & & $(0.00464)$ & & & \\
\hline composer-age controls & yes & yes & yes & yes & yes & yes \\
\hline composer fe & yes & yes & yes & yes & yes & yes \\
\hline year fe & yes & yes & yes & yes & yes & yes \\
\hline country fe & yes & yes & yes & yes & yes & yes \\
\hline Observations & 5260 & 5260 & 5260 & 5260 & 4115 & 5260 \\
\hline R-squared & 0.190 & 0.189 & 0.191 & 0.194 & 0.212 & 0.193 \\
\hline
\end{tabular}


TABLE 4. Heterogeneity of Forced Migrants.

\begin{tabular}{|c|c|c|c|c|c|c|c|}
\hline & emigrate & emigrate & emigrate & emigrate & emigrate & emigrate & emigrate \\
\hline EXPLANATORY VARIABLES & (1) & $(2)$ & (3) & (4) & (5) & (6) & (7) \\
\hline Continental war & $\begin{array}{l}0.0707^{* *} \\
(0.0300)\end{array}$ & & $\begin{array}{l}0.0707^{* *} \\
(0.0300)\end{array}$ & $\begin{array}{l}0.0764^{* *} \\
(0.0350)\end{array}$ & $\begin{array}{c}0.0468 \\
(0.0365)\end{array}$ & $\begin{array}{l}0.00317 \\
(0.0298)\end{array}$ & $\begin{array}{l}-0.0124 \\
(0.0311)\end{array}$ \\
\hline Intra-state war & $\begin{array}{c}0.0168 \\
(0.0302)\end{array}$ & & $\begin{array}{c}0.0168 \\
(0.0302)\end{array}$ & $\begin{array}{c}0.101 \\
(0.0798)\end{array}$ & $\begin{array}{l}0.0429 \\
(0.103)\end{array}$ & $\begin{array}{c}0.0119 \\
(0.0468)\end{array}$ & $\begin{array}{c}0.132 \\
(0.178)\end{array}$ \\
\hline Murray's Index Score (MIS) & & $\begin{array}{l}0.0115^{* *} \\
(0.00497)\end{array}$ & $\begin{array}{c}0.000507 \\
(0.000782)\end{array}$ & $\begin{array}{r}-0.000825 \\
(0.00165)\end{array}$ & & & $\begin{array}{l}0.00508^{* * *} \\
(0.000881)\end{array}$ \\
\hline $\begin{array}{l}\text { Music-related engagement of } \\
\text { any family member (Family) }\end{array}$ & & $\begin{array}{l}-0.562^{\star *} \\
(0.266)\end{array}$ & $\begin{array}{c}-0.0834^{* \star *} \\
(0.0247)\end{array}$ & & $\begin{array}{l}-0.0561 \\
(0.0882)\end{array}$ & & $\begin{array}{l}-0.00615 \\
(0.0335)\end{array}$ \\
\hline $\begin{array}{l}\text { Duration of music-related } \\
\text { education (Education) }\end{array}$ & & $\begin{array}{l}0.0920^{* *} \\
(0.0440)\end{array}$ & $\begin{array}{l}0.00402^{*} \\
(0.00214)\end{array}$ & & & $\begin{array}{l}0.00464^{* *} \\
(0.00189)\end{array}$ & $\begin{array}{c}0.00938^{* \star *} \\
(0.00236)\end{array}$ \\
\hline Continental war * MIS & & & & $\begin{array}{l}-0.000439 \\
(0.00126)\end{array}$ & & & $\begin{array}{l}-0.00170 \\
(0.00124)\end{array}$ \\
\hline Intra-state war * MIS & & & & $\begin{array}{l}-0.00709^{*} \\
(0.00366)\end{array}$ & & & $\begin{array}{l}-0.00716^{\star *} \\
(0.00364)\end{array}$ \\
\hline Continental war * Family & & & & & $\begin{array}{c}0.0248 \\
(0.0347)\end{array}$ & & $\begin{array}{c}0.0368 \\
(0.0403)\end{array}$ \\
\hline Intra-state war * Family & & & & & $\begin{array}{l}-0.0209 \\
(0.0525)\end{array}$ & & $\begin{array}{l}-0.0116 \\
(0.0617)\end{array}$ \\
\hline Continental war * Education & & & & & & $\begin{array}{l}0.00630^{* *} \\
(0.00276)\end{array}$ & $\begin{array}{r}0.00749^{* * *} \\
(0.00264)\end{array}$ \\
\hline Intra-state war * Education & & & & & & $\begin{array}{l}0.000711 \\
(0.00498)\end{array}$ & $\begin{array}{r}-0.000578 \\
(0.00455)\end{array}$ \\
\hline composer-age controls & yes & yes & yes & yes & yes & yes & yes \\
\hline composer fe & yes & yes & yes & yes & yes & yes & yes \\
\hline year fe & yes & yes & yes & yes & yes & yes & yes \\
\hline country fe & yes & yes & yes & yes & yes & yes & yes \\
\hline Observations & 5260 & 5260 & 5260 & 5260 & 5260 & 5260 & 5260 \\
\hline R-squared & 0.189 & 0.158 & 0.190 & 0.189 & 0.192 & 0.189 & 0.194 \\
\hline
\end{tabular}


TABLE 5. Destination of Migration. Characteristics and Differences to Origin Country.

\begin{tabular}{|c|c|c|c|c|}
\hline & $\begin{array}{c}\text { All } \\
\text { migration } \\
(1) \\
\end{array}$ & $\begin{array}{l}\text { Migration during } \\
\text { peace in origin } \\
\text { country } \\
\text { (2) }\end{array}$ & $\begin{array}{l}\text { Migration during } \\
\text { war in origin } \\
\text { country } \\
\text { (3) }\end{array}$ & $\begin{array}{c}\text { Difference } \\
(3)-(2)\end{array}$ \\
\hline Been before at destination & $\begin{array}{l}0.559^{*} \\
(0.021)\end{array}$ & $\begin{array}{c}0.546 \\
(0.023)\end{array}$ & $\begin{array}{c}0.640 \\
(0.056)\end{array}$ & $\begin{array}{l}0.094^{*} \\
(0.062)\end{array}$ \\
\hline Destination is birth country & $\begin{array}{l}0.277^{\star} \\
(0.019)\end{array}$ & $\begin{array}{c}0.240 \\
(0.050)\end{array}$ & $\begin{array}{c}0.283 \\
(0.021)\end{array}$ & $\begin{array}{c}0.043 \\
(0.056)\end{array}$ \\
\hline $\begin{array}{l}\text { Difference in number of } \\
\text { composers }\end{array}$ & $\begin{array}{l}0.754^{*} \\
(0.420)\end{array}$ & $\begin{array}{c}1.054 \\
(0.447)\end{array}$ & $\begin{array}{l}-1.093 \\
(1.193)\end{array}$ & $\begin{array}{l}-2.148^{*} \\
(1.209)\end{array}$ \\
\hline Difference in population & $\begin{array}{c}-349.1 \\
(3583.9)\end{array}$ & $\begin{array}{c}2658.2 \\
(3682.3)\end{array}$ & $\begin{array}{l}-22659.6 \\
(12425.1)\end{array}$ & $\begin{array}{c}-25317.8^{*} \\
(11012.3)\end{array}$ \\
\hline Difference in GDP pc & $\begin{array}{c}110.5 \\
(0.155)\end{array}$ & $\begin{array}{c}207.4 \\
(0.155)\end{array}$ & $\begin{array}{l}-608.2 \\
(0.618)\end{array}$ & $\begin{array}{l}-815.6^{*} \\
(0.478)\end{array}$ \\
\hline
\end{tabular}

NOTE: Standard errors are in parentheses. Differences are calculated between destination country and origin country. $*$ denotes coefficients in Columns (1) and (4) that are different from zero at the $10 \%$ confidence interval. 


\section{Appendix}

APPENDIX 1. Migration and War-related Violence.

\begin{tabular}{|c|c|c|}
\hline & emigrate & emigrate \\
\hline EXPLANATORY VARIABLES & (1) & $(2)$ \\
\hline \multirow{2}{*}{ Continental war } & $0.0707^{\star *}$ & \\
\hline & $(0.0300)$ & \\
\hline \multirow{2}{*}{ Intra-state war } & 0.0168 & \\
\hline & $(0.0302)$ & \\
\hline \multirow{2}{*}{$\begin{array}{l}\text { Continental war deaths adjusted by } \\
\text { pre-war population }\end{array}$} & & $0.105^{\star *}$ \\
\hline & & $(0.0469)$ \\
\hline \multirow{2}{*}{$\begin{array}{l}\text { Intra-state war deaths adjusted by pre- } \\
\text { war population }\end{array}$} & & $0.164^{*}$ \\
\hline & & $(0.0998)$ \\
\hline composer-age controls & yes & yes \\
\hline composer fe & yes & yes \\
\hline year fe & yes & yes \\
\hline country fe & yes & yes \\
\hline Observations & 5260 & 5260 \\
\hline R-squared & 0.19 & 0.19 \\
\hline \multicolumn{3}{|c|}{$\begin{array}{l}\text { NOTE: Probit estimation techniques are employed. We reported pseudo } \mathrm{R} \\
\text { square terms. Standard errors are clustered at the composer level and reporte } \\
\text { in parentheses. Composer-specific age time trend is estimated with a quadrati } \\
\text { age polynomial. } * * * / * * / * \text { indicate estimates that are significantly different fron } \\
\text { zero at } 99 / 95 / 90 \text { percent confidence. }\end{array}$} \\
\hline
\end{tabular}

